\title{
Vervaardiging van fluoorgas vir laboratoriumgebruik: Proses-ontwerp en -bedryf
}

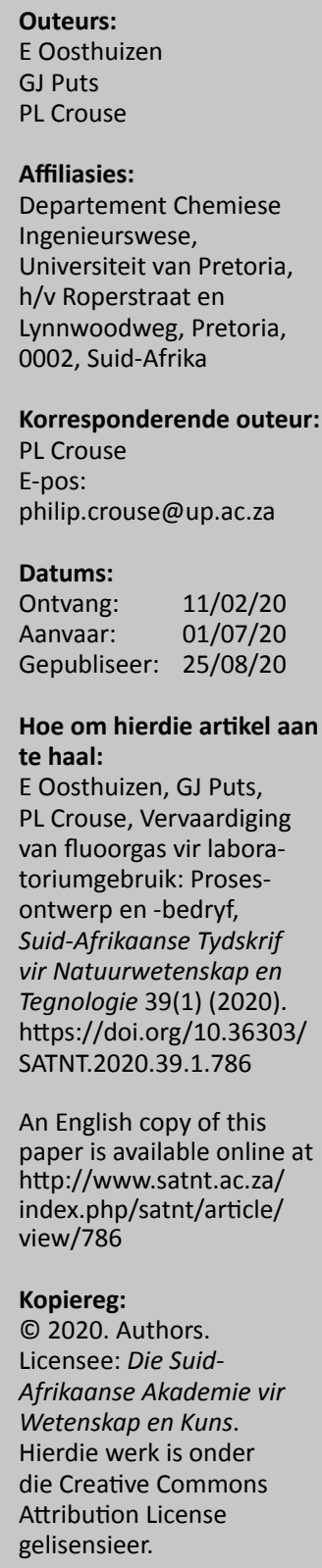

\begin{abstract}
'n Proses vir die kleinskaalse laboratoriumvervaardiging van fluoorgas met $\mathrm{CaF}_{2}$ as die invoer-reagens is ontwerp en in bedryf gestel. Die eerste stap maak gebruik van 'n lotreaktor wat $\mathrm{CaF}_{2}$ na anhidriese $\mathrm{HF}$ omskakel deur reaksie met anhidriese swawelsuur. Die vervaardigde HF word gestoor in 'n oordragsvat en dan na 'n Pauling-tipe fluoorsel, wat vooraf met KF·HF gelaai is, oorgedra. Die elektroliet, KF-2HF, wat by die bedryfstemperatuur van die sel in die vloeistoffase is, word in-situ gevorm. Waterstoffluoried (HF), op sigself, is 'n swak suur en is nie elektries geleidend genoeg vir elektroliese nie. Die gebrekkige elektriese geleidingsvermoë van HF word omseil deur gebruik te maak van KF-2HF as elektroliet. KF-2HF dissosieer na die ione $\mathrm{K}^{+}$en $\mathrm{F}_{2} \mathrm{H}^{-}$in $\mathrm{HF}$, in die vloeistoffase en gelei eletrisiteit genoegsaam om as elektroliet op te tree. Die HF lotreaktor toon 'n omskakelingsrendement van $70 \%$. Die fluoorsel het 'n waarneembare bo-potensiaal van $2.7 \mathrm{~V}$ en die voltammetriese kromme toon die verwagte elektriese gedrag.
\end{abstract}

Sleutelwoorde: Anhidriese waterstoffluoried; fluoorgas; elektrolise; Pauling-sel

Manufacture of fluorine gas for laboratory use: Process design and operation: A process for the laboratory-scale production of fluorine gas using $\mathrm{CaF}_{2}$ as precursor was designed and commissioned. The first step uses a batch reactor in which anhydrous hydrogen fluoride (AHF) is produced by the reaction of $\mathrm{CaF}_{2}$ with sulphuric acid. The AHF is stored, then transferred to a Pauling-type cell, preloaded with KF·HF. The electrolyte, KF-2HF, which is a liquid at the working temperature, is formed in situ. AHF by itself is a weak acid and is is not sufficiently electrically conductive for direct electrolysis. This problem is bypassed by using KF-2HF. Above its melting point, $\mathrm{KF} \cdot 2 \mathrm{HF}$ dissociates to form $\mathrm{K}^{+}$en $\mathrm{F}_{2} \mathrm{H}^{-}$in $\mathrm{HF}$, and is sufficiently conductive for electrolysis. The HF batch reactor showed provideda yield of $70 \%$. The fluorine cell afforded an observable overpotential of $2.7 \mathrm{~V}$, and its voltametric curve displayed the expected behaviour.

Keywords: Anhydrous hydrogen fluoride; fluorine gas; electrolysis; Pauling cell

\section{Inleiding}

Die vervaardiging van fluoorgas is ' $n$ bekende proses in Suid-Afrika en is geskiedkundig gebruik vir die verryking van uraan vir gebruik in die kernindustrie, o.a. in siviele kern-kragopwekking en verskeie militêre toepassings. Fluoorgasvervaardiging geskied deur die elektrochemiese splitsing van waterstoffluoried $(\mathrm{HF})$ tot $\mathrm{F}_{2}(\mathrm{~g})$ en $\mathrm{H}_{2}(\mathrm{~g})$. Waterstoffluoried word op sy beurt vervaardig uit kalsiumfluoried $\left(\mathrm{CaF}_{2}\right)$, ook bekend as vloeispaat. Die proses is steeds van groot ekonomiese belang aangesien Suid-Afrika van die grootste vloeispaat-reserwes ter wêreld het. Hierdie mineraal word egter uitgevoer en in die buiteland veredel, tot nadeel van die SuidAfrikaanse ekonomie. Die kommersiële fluooraanleg by Necsa is tans die enigste bron van fluoorgas in Suid-Afrika. 'n Toename in fluoorverbruik vir oppervlakfluorering van polimeerprodukte en die direkte fluorering van organiese verbindings word verwag as gevolg van hernude belangstelling in die herbou en verdere uitbou van die Suid-Afrikaanse fluoorchemieindustrie deur verskeie regeringsgedrewe industriële-ontwikkelingskemas. Realistiese markvoorspelling dui daarop dat die industrie in die toekoms mag neig na kleinskaalse vervaardiging van fluoorgas by die onderskeie verbruikspunte as gevolg van die gevaar verbonde aan die grootmaat vervaardiging- en berging van fluoorgas, sowel as vervoer van die gas. Die langtermyndoelwit van hierdie navorsing is dus die ontwerp van bekostigbare, veilige lotreaktors vir laboratorium- en kleinsakegebruik. Die bemagtiging van navorsingsinstansies om hierdie klein ontwerpe te bestudeer en te toets is ' $n$ eerste vir fluoorkundigheid in Suid-Afrika. Die toerusting wat hierdie doel ondersteun, is ontwerp en getoets by die Universiteit van Pretoria. 
Aangesien die elektroliet, KF-2.2HF, nie maklik bekombaar is nie, is die nodige lotreaktor vir die vervaardiging van anhidriese waterstofluoried (AHF) ook ingesluit. Beide reaktore en 'n oordragsvat vir die AHF is ontwerp, vervaardig, in bedryf gestel, en getoets.

\section{Proses-oorsig en veiligheid}

Figuur 1 toon 'n vereenvoudigde prosesvloeidiagram van die fluoorgasvervaardigingsproses. Anhidriese HF is nie maklik bekombaar nie en moet daarom plaaslik vervaardig word. Gevolglik word $\mathrm{CaF}_{2}$ eers na $\mathrm{HF}(\mathrm{g})$ omgeskakel in die HF-lotreaktor. Die gasfasige HF word in die oordragsvat vasgevries tydens die HF vervaardigingsproses en word dan weer vanaf hierdie vat na die fluoorsel, wat vooraf met vaste KF·HF gelaai is, oorgedra vir die elektrochemiese vervaardiging van $\mathrm{F}_{2}(\mathrm{~g})$. Waterstoffluoried is op sigself 'n swak suur en is elektries nie-geleidend. KF-2HF wat as elektroliet gebruik is wel geleidend bo sy smeltpunt. Vir die laboratoriumproses word die byprodukte as afval weggemaak.

Veiligheidsaspekte is uiters belangrik. $\mathrm{HF}$ en $\mathrm{F}_{2}$ is uiters gevaarlik, so ook baie fluoorhoudende verbindings. Die bylae bevat ' $n$ kort opsomming van die nodige veiligheidsfasette.

\section{Toerustingontwerp en bedryfs- metodes HF-lotreaktorontwerp}

Vlekvrye staal, aluminium en lood toon genoegsame chemiese weerstand teen $\mathrm{H}_{2} \mathrm{SO}_{4}$ (aq) en $\mathrm{HF}$ vir laboratoriumgebruik (Craig and Anderson, 1995, Francis, 2009). As ' $n$ eerste poging is twee weergawes van die reaktor uit aluminiumknuppels gemasjineer (Macur, 2016) aangesien aluminium beter chemiese weerstand in die teenwoordigheid van waterige HF bied. Die silindriese reaktore is met opskroefdeksels geseël. Vir beide weergawes het die fluoorelastomeer o-ring tussen die romp en deksel gefaal en die reaktore is derhalwe nie verder gebruik nie.

Figuur 2 toon 'n P\&ID (pyp- en instrumentdiagram) vir die reaktor, saam met 'n foto van die finale reaktor soos gebruik.

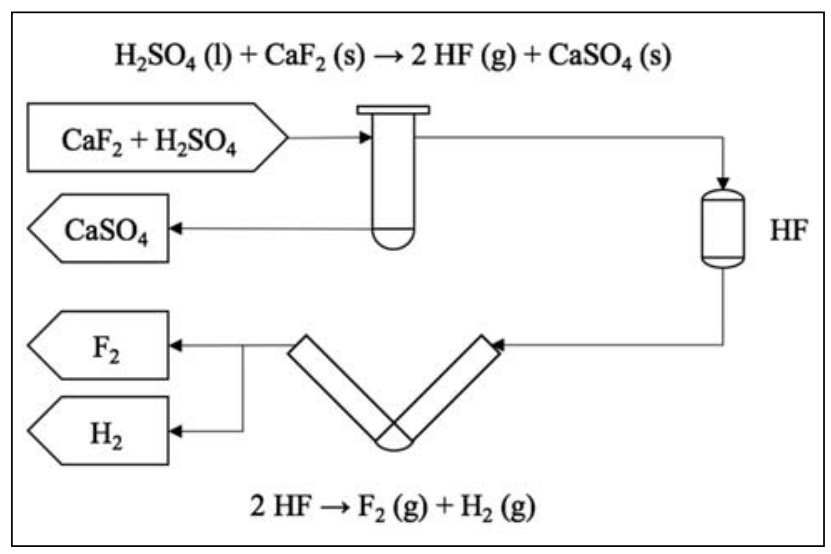

FIGUUR 1: Prosesvloeidiagram van die laboratoriumsisteem. 'n Eenvoudiger ontwerp is daargestel met 'n $248 \mathrm{~mm}$ DN $6521 \frac{1}{2}$ " skedule 40316 vlekvrye-staalpyp. Die pyp is aan die onderkant met 'n deksel en sweislas geseël en van 'n DN 65 SANS 1123 tabel 1600/3 opglipflens voorsien. Die bo-kant van die reaktor word met 'n DN 65 SANS 1123 tabel 1600 blinde flens afgedig. Hierdie flens dien ook as toegangspunt vir die laai van reaktante en is dus voorsien van 'n klep met behulp van $1 / 4$ " NPT skroefdraad. Die flense beskik oor verhewe seëlvlakke ter versekering van lekdigte afdigting. Alle toebehoorsels in die ontwerp is Swagelok-komponente vervaardig uit 316 vlekvrye staal. 'n Viton pakstuk met 'n dikte van $1 \mathrm{~mm}$ word tussen die flense gebruik.

\section{HF-lotreaktorbedryf}

Die lotreaktor word gemonteer in die eksperimentele opstelling soos in Figuur 3 getoon. Die reaktorwand is voorsien van 'n $400 \mathrm{~W}$ verhittingsmantel en 'n J-tipe termokoppel. Die temperatuur word beheer deur 'n Shinko PIDbeheerder met fabrieksbeheerverstellings. Die metaalraam vir opstelling is ontwerp om die reaktor en oordragvat te ondersteun sodat die volledige opstelling in ' $n$ standaarddampkas bedryf kan word. 'n Deursigtige PFA vloeilyn met 'n T-stuk in die lyn word gebruik om die lotreaktor en oordragvat te verbind. Die syvloei van die T-stuk word deur middel van 'n afsluitklep aan die vakuumpomp gekoppel.

'n Maksimum van 60 g HF kan per lopie vervaardig word. Die reaksie word uitgevoer met 'n 5-maal molare oormaat swawelsuur. Die beperkende gedrag van die reaksie is die

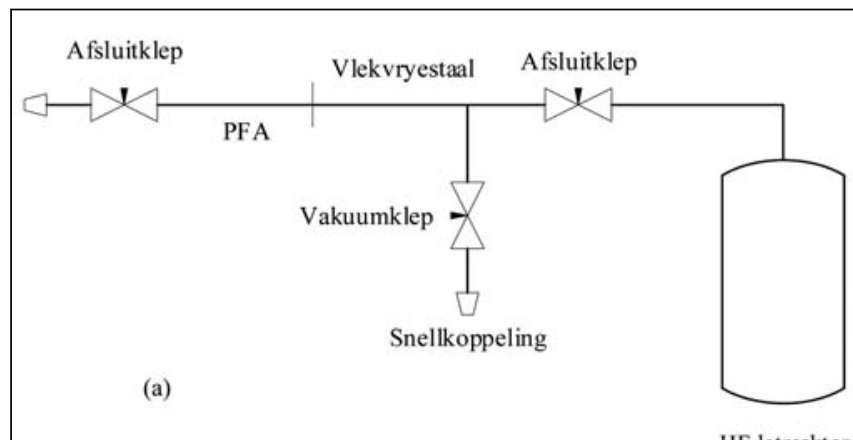

HF-lotreaktor

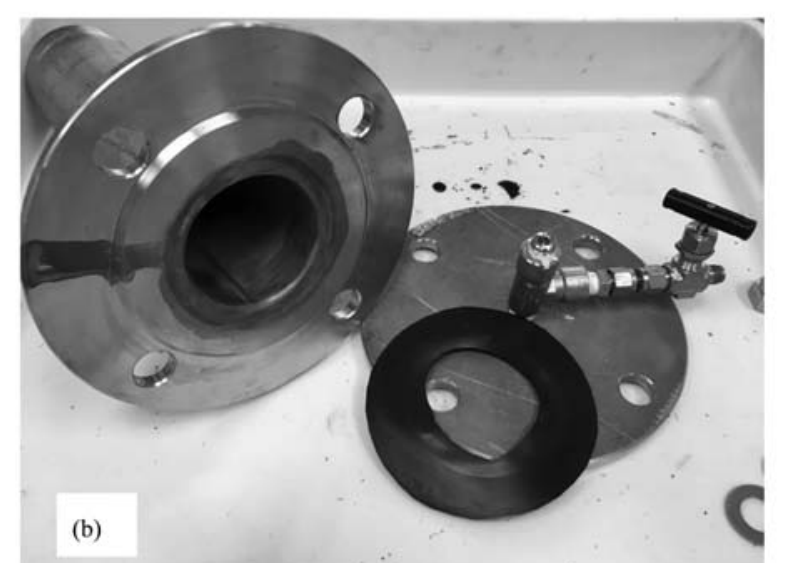

FIGUUR 2: HF-lotreaktor. (a) Pyp-en instrumentdiagram van die opstelling, en (b) 'n foto van die reaktor. 


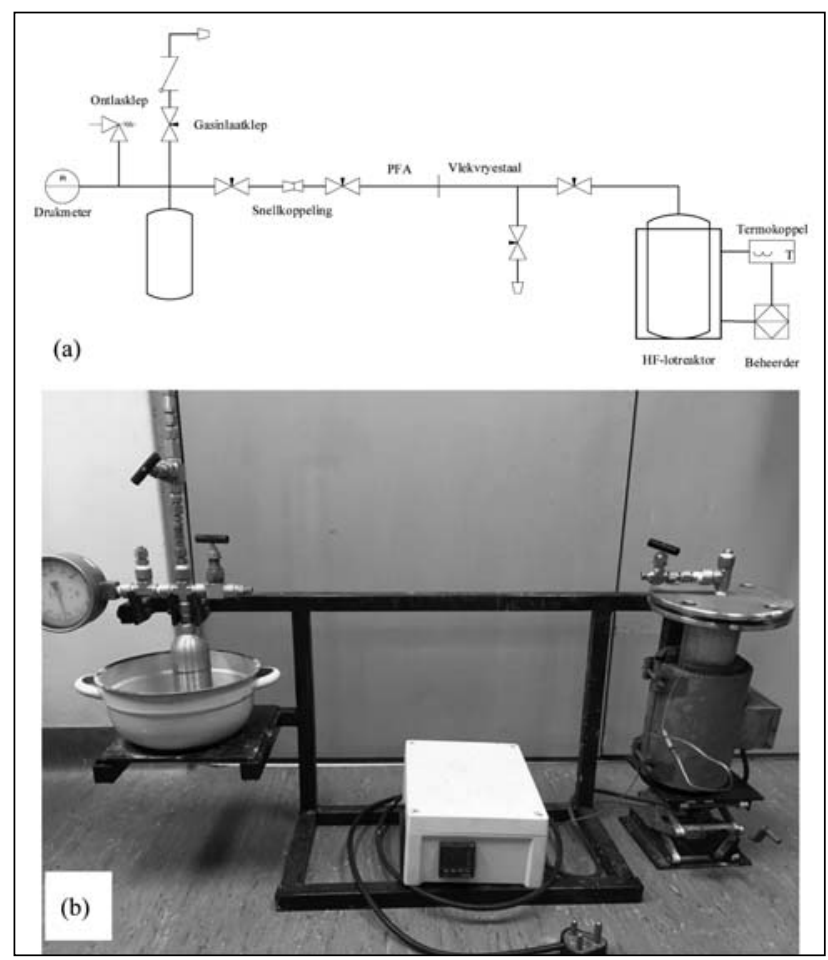

FIGUUR 3: HF-lotreaktor eksperimentele opstelling. (a) P\&ID, en (b) foto.

verskeie fisiese fases wat tydens die reaksie vorm (Aigueperse et al., 2000). Die reaksiemengsel verander van 'n viskose vloeistof na 'n poeier soos reaksie (1) onder verloop. Hierdie gedrag lei tot meesleuring van die reagense deur die gasfasige produk. Die reaksievolume is gevolglik vergroot om die verskynsel te voorkom.

$$
\mathrm{H}_{2} \mathrm{SO}_{4}(l)+\mathrm{CaF}_{2}(\mathrm{~s}) \rightarrow \mathrm{CaSO}_{4}(\mathrm{~s})+2 \mathrm{HF}(\mathrm{g})
$$

Figuur 4 toon 'n foto en P\&ID van die oordragsvat waarin anhidriese HF gestoor word. Daar word eksplisiet na hierdie stoorvatjie verwys gedurende verhitting/verkoeling van die HF-inhoud. Die stoorvatjie, tesame sy toebehoorsels, word na verwys as die HF-oordragsvat. Die oordragsvat is van 316 vlekvrye staal vervaardig en bestaan, soos die lotreaktor, slegs uit standaard-komponente. Swagelok-kompressieseëls en $1 / 4$ " buise is deurgaans gebruik. Die horisontale vloeilyn word gebruik gedurende die laai of ontlaai van die vat. Die vertikale vloeilyn is ' $n$ buis wat tot na aan die boom van die stoorvat reik. HF kan onttrek word deur $\mathrm{N}_{2}$ (g) deur die HF(l)-reserwe te borrel. 'n Voorbeeldtoepassing is termogravimetriese analise van stowwe in die teenwoordigheid van 'n HF(g) atmosfeer.

Gedurende bedryf van die lotreaktor word die stoorvatjie onderaan die oordragsvat reeds vooraf met vloeibare $\mathrm{N}_{2}$ verkoel om enige teenwoordige $\mathrm{HF}$ vas te vries en verliese tydens evakuering te voorkom. Die reaktor is steeds by kamertemperatuur nadat dit met reagense gelaai en verseël is. Daarna word die volledige sisteem ge-evakueer. Die nodige drukverskil vir oordrag word dus onderhou soos die $\mathrm{HF}$ (g)-produk in die stoorvat vasgevries word. Wanneer HF vanuit die oordragsvat oorgedra word, word die stoor-

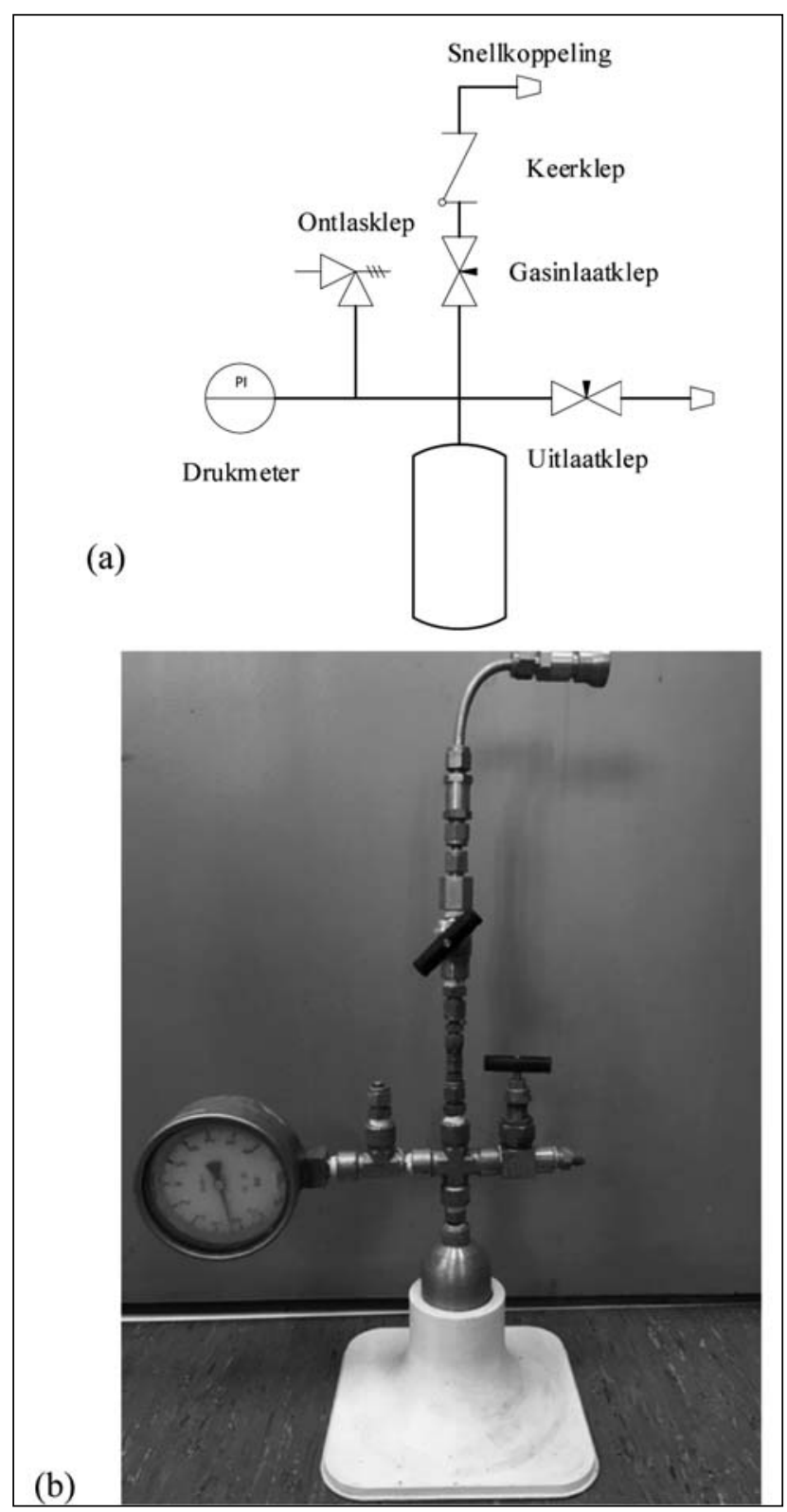

FIGUUR 4: Anhidriese-HF-oordragsvat. (a) P\&ID, en (b) foto van die vat in 'n 3D-gedrukte staander.

vatjie in verhitte water geplaas om weer 'n gunstige, positiewe drukverskil teweeg te bring deur die $\mathrm{HF}(\mathrm{l})$ in die stoorvatjie af te damp.

Die lotreaktor word voor en na elke lopie met water gewas en in 'n droogoond by $50{ }^{\circ} \mathrm{C}$ geplaas om te verseker dat geen water in die reaktor teenwoordig is nie. Die droë reaktor word gelaai met 'n bekende massa en die flens verseël, met die klep geslote. Die vakuum word vir ongeveer 10 sekondes onderhou. Hierna word die klep na die vakuumpomp gesluit en die pomp afgeskakel. Die verhittingsklos word dan aangeskakel en die stelpunt na $80{ }^{\circ} \mathrm{C}$ verstel. Na een uur word die stelpunt na $150{ }^{\circ} \mathrm{C}$ en na nog 'n uur na $170{ }^{\circ} \mathrm{C}$ verstel. Die Viton pakstuk is ver genoeg van die verhittingsklos verwyder om nie bo die 205 ${ }^{\circ} \mathrm{C}$ dienstemperatuurlimiet te verhit nie. Elke lopie duur in totaal ongeveer 3 uur vandat die verhittingsklos aange- 
skakel is. Die deursigtige oordragbuis laat die inspeksie toe van gasvloeitempo wat aanduidend is van reaksietempo. Die drukmeterlesing word gebruik om te verseker dat die $\mathrm{HF}$ in die stoorvatjie vasgevries is.

$\mathrm{Na}$ afloop van die reaksie word die oordragsvatklep gesluit en die oordragbuis ontkoppel. Die verhittingsklos word afgeskakel en enige oorblywende HF word toegelaat om te ontsnap in die omgewing in. Om die massa HF wat geproduseer word te kwantifiseer, word die oordragsvat voor en na afloop van 'n lopie geweeg.

\section{Fluoorsel-ontwerp}

Die fluoorsel word by ' $\mathrm{n}$ temperatuur van ongeveer $80^{\circ} \mathrm{C}$ en atmosferiese druk bedryf. Die sel is ontwerp as ' $n$ mediumtemperatuurreaktor met 'n elektrolietsamestelling van KF-2.2HF (Rudge, 1971). Elke lading HF kan tot $10 \mathrm{~g} \mathrm{~F}_{2}$ (g) lewer. Die fluoorsel maak gebruik van die Paulingselgeometrie (Pauling, 1957) wat soortgelyk is aan die geometrie wat deur Moissan gebruik is (Cady et al., 1942). 'n Lae energie-rendement kan van hierdie ontwerp verwag word as gevolg van die mate waartoe die elektrodes van mekaar afgeskerm word. 'n Hoë potensiaalverlies aan die sel se interne stroombaan (Walsh, 1993) word dus voorspel. Gegewe dat veilige bedryf van die sel primêr was, is die energierendement as van minder belang beskou. Die gekose vorm van die selromp verseker dat die plofbare herkombinasie van die produkgasse nie plaasvind nie (Shia, 2003). Sulke verliese ter wille van veiligheid is egter algemeen bekend vir fluoorselle waar Monel-skerms gebruik word om herkombinasie te vermy (Roustan et al., 1998).

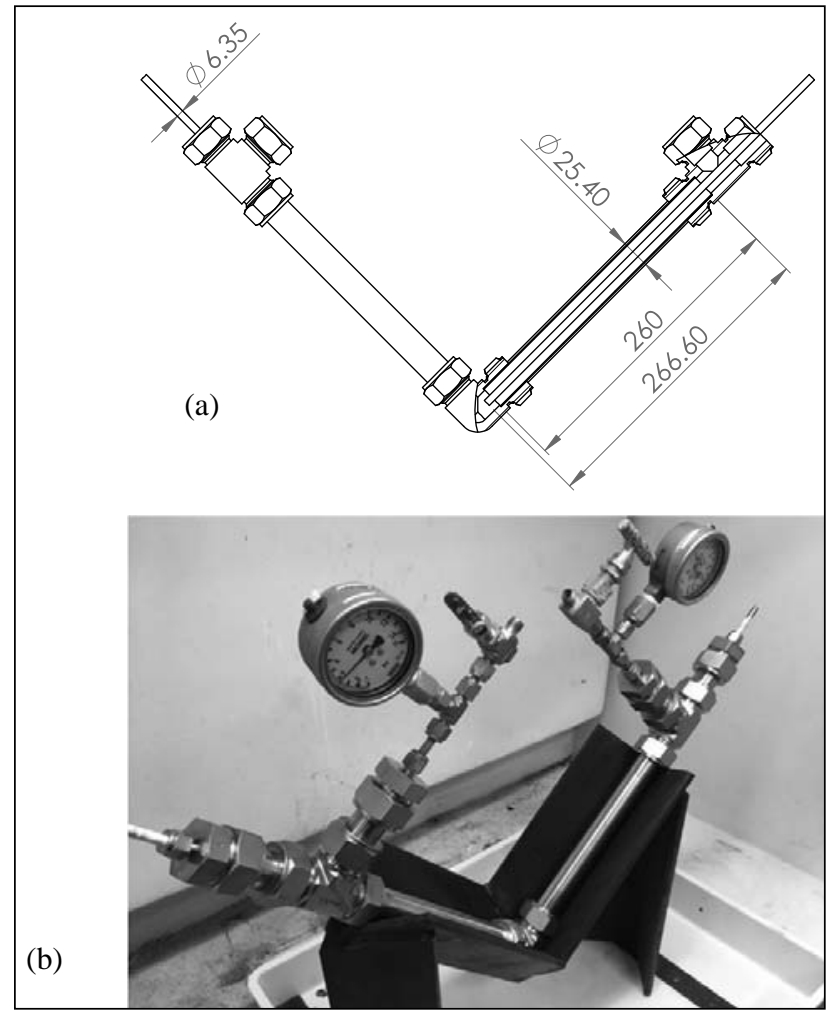

FIGUUR 5: (a) Meganiese ontwerpskets, en (b) 'n foto van die fluoorsel.
Die meganiese ontwerpskets van die sel word in Figuur 5 getoon. Slegs die belangrike afmetings word in die skets verskaf. Die lengtes van buise om die nodige toebehore, drukmeters en kleppe aan die sel te koppel is arbitrêr.

Vir die selromp en toebehore is 304 en 316 vlekvrye staal gebruik ten spyte van die laer as gewenste weerstand teen HF (Craig and Anderson, 1995). Aanval deur $\mathrm{F}_{2}(\mathrm{~g})$ behoort egter nie oormatige korrosie van die materiaal te veroorsaak nie (Rudge, 1971). Sagte staal en nikkel is aangewend vir die katode en anode. Dit is moontlik om die nikkel met nie-grafitiese koolstof te vervang (Groult et al., 2005, Ring and Royston, 1973). Hierdie verandering van anodemateriaal word aanbeveel vir verdere navorsing aangesien meeste kommersiële aanlegte van koolstof gebruik maak (Rudge, 1971). Só 'n opstelling sal dit ook moontlik maak om die interaksie van $\mathrm{F}_{2}(\mathrm{~g})$ met die anode te ondersoek aangesien die gas nie maklik van die koolstofoppervlak wegbreek nie, maar lensvormige borrels vorm (Groult, 2003). Afgesien van die interessante effekte wat hierdie borrels op stroomverspreiding in die sel het, is daar ook oppervlakreaksie tussen die gasproduk en die koolstof (Shia, 2003).

Die sel is ontwerp vir 'n stroomdigtheid van ongeveer 100 $\mathrm{mA} \cdot \mathrm{cm}^{-2}$ (Leech, 1949) wanneer 'n stroom van 3.6 A onderhou word. Die gevolglike aktiewe lengte van beide die anode en katode is dus $200 \mathrm{~mm}$ wanneer $1 / 4$ " stawe gebruik word. Die finale lengte van die elektrodes vir elektriese koppeling ekstern tot die sel, word bepaal deur die lengte van die buise en die nodige toebehore wat aan elke reaksiebuis monteer word. Alle komponente is standaard en die sel bestaan dus slegs uit buise, vernoustukke, 'n elmboogstuk en T-stukke. Die enigste spesiale wysigings is die gebruik van PFA krimphulse, wat verseker dat die elektrodes, waar hulle op die sel monteer word, nie 'n elektriese kortsluiting oor die selromp veroorsaak nie. Die selromp het dus ook 'n $0 \mathrm{~V}$ potensiaal vir veilige gebruik.

Die interne skouers van die vernoustukke wat die elektrodes huisves is uitgeboor na $6.5 \mathrm{~mm}$ tot $6.7 \mathrm{~mm}$ sodat die elektrodes met hul isolasiemateriaal deurgesteek kan word.

Die fluoorsel is getoets om gasdig te wees tot 'n druk van 2 bar meterdruk. Die diameter van die reaksiebuise is gekies sodat die verandering in elektrolietvlak gedurende bedryf nie die stroomdigtheid buite bedryfswaardes van 80 $\mathrm{mA} \cdot \mathrm{cm}^{-2}$ tot $100 \mathrm{~mA} \cdot \mathrm{cm}^{-2}$ neem nie (Leech, 1949). Hiermee saam moet die sel die nodige massa $\mathrm{F}_{2}(\mathrm{~g})$ produseer voor dit nodig is om die HF weer aan te vul. Gedurende bedryf wissel die stroomdigtheid en elektroliet samestelling van $112 \mathrm{~mA} \cdot \mathrm{cm}^{-2}$ en $\mathrm{KF} \cdot 2.2 \mathrm{HF}$ by ' $\mathrm{n}$ vol lading na $118 \mathrm{~mA} \cdot \mathrm{cm}^{-2}$ en $\mathrm{KF} \cdot 2.02 \mathrm{HF}$ nadat $10 \mathrm{~g}$ produk vervaardig is. Die reaksiebuise is $250 \mathrm{~mm}$ lank om voorsiening te maak vir 'n vry-ruimte van $50 \mathrm{~mm}$ bo die elektrolietvlak om te verseker dat die gesmelte elektroliet nie tot die drukmeters en $1 / 4$ " buise vloei en daar vries nie. 


\section{Fluoorsel-bedryf}

Voor die fluoorsel se eerste bedryf word die sel met $215 \mathrm{~g}$ $\mathrm{KF} \cdot \mathrm{HF}(\mathrm{s})$ gelaai om die KF·2.2HF elektroliet te kan berei. Laaiwerk word gedoen deur die 1 " kompressieseëls aan die bo-kant van die reaksiebuise oop te skroef en agterna weer vas te skroef. Die kleppe word gesluit en die sel by kamertemperatuur vir 5 minute onder vakuum geplaas om enige atmosferiese gasse en meeste waterdamp te verwyder. Die teenwoordigheid van waterdamp het 'n merkwaardige effek op die leeftyd van die reaktor aangesien $\operatorname{HF}(\mathrm{aq})$ besonders korrosief is. Gasdigtheid word getoets deur die sel tot 2 bar meterdruk met stikstof te laai. Hierna word die sel aan die oordragvat gekoppel en in 'n metanol-ys mengsel verkoel en ge-evakueer. Die kristallyne sout laat toe dat die hele sel sodoende evakueer word en die ander reaksiebuis kan vooraf aan die oordragsvat gekoppel word met die fluoorsel se klep ontsluit. Sodoende word die oordragsbuis vanaf die oordragsvat na die fluoorsel ook evakueer. Die 1 " reaksiebuis aan die kant van die vakuumpomp word dan afgeseël en die pomp afgeskakel.

Die oordragsvat se stoorvatjie word hierna in warm water geplaas en die oordragsvat se klep ontsluit sodat die drukverskil tussen die verkoelde fluoorsel en die warm stoorvatjie die oordrag van $\mathrm{HF}(\mathrm{g})$ teweeg kan bring. Gedurende hierdie proses verdamp die HF in die stoorvatjie en kondenseer dit in die fluoorsel. Vir die eerste lading nadat die fluoorsel met KF·HF(s) gelaai is, word $66.2 \mathrm{~g} \mathrm{HF}(\mathrm{g})$ na die fluoorsel oorgedra om die korrekte elektrolietsamestelling te bewerkstellig.

Die fluoorsel word uit die metanolysmengsel verwyder en gelaat om stadig tot kamertemperatuur te verhit. Hierna word verhitting in $10{ }^{\circ} \mathrm{C}$ stappe gedoen sodat die druk binne die sel nie bo 2 bar meterdruk styg nie. Die sel word by 'n temperatuur van $100{ }^{\circ} \mathrm{C}$ gehou totdat interne stroombaansluiting waargeneem word m.b.v. 'n klokkietoets. Hierna word die temperatuur verstel na die bedryfstemperatuur van $80{ }^{\circ} \mathrm{C}$ en die sel word bedryf. Die massa $\mathrm{HF}(\mathrm{g})$ wat oorgedra is na die fluoorsel word gekontroleer deur die oordragsvat voor en na die oordrag te weeg. Temperatuur word beheer word met ' $n$ Shinko PID beheerder en J-tipe termokoppel word geplaas tussen die reaksiebuiswand en 'n verhittingsband. Koolstofwol word om beide die reaksiebuise met hul verhittingsband gedraai om energieverliese te beperk.

Die prosedure wat hier beskryf word, word herhaal om die fluoorsel se HF reserwe aan te vul na gebruik in die laboratorium. 'n Elektronbalans word gebruik om die gebruik van die HF reaktant te bepaal. Die Coulomb-effektiwiteit is as $70 \%$ geneem (Rudge, 1971).

\section{Opstellingkostes}

Die koste van die reaktore ten tye van publikasie word ingesluit om voornemende navorsers by te staan met kapitaalbegroting. Tabel 1 toon oorhoofse koste van elke reaktor. In die aangeduide kostes word die koste van buise, staanders, seëlmateriaal en reagense nie ingesluit nie.

TABEL 1: Reaktorkostes in die jaar 2018

\begin{tabular}{l|c}
\hline Reaktor & Koste (ZAR) \\
\hline HF-lotreaktor & 4800 \\
\hline Fluoorsel & 23400
\end{tabular}

\section{Eksperimenteel Chemikalieë}

$97 \%$ suiwer $\mathrm{CaF}_{2}$ poeier vanaf Merck is gebruik, tesame met $98 \%$ swawelsuur verskaf deur ACE. Die elektrolietvoorganger was $99.99 \%$ suiwer KF·HF sout vanaf Sigma Aldrich..

\section{Tipiese eksperimentele beplanning}

Om die $215 \mathrm{~g}$ KF·HF(s) met HF tot 'n verhouding van $\mathrm{KF} \cdot 2.2 \mathrm{HF}(\mathrm{s})$ te verryk, is $66.2 \mathrm{~g} \mathrm{HF}$ nodig. Om enige meesleuring van die reaksiemengsel te voorkom word daar dus twee lopies gedoen om die HF te vervaardig (Tabel 2) Die vervaardigde HF word na die fluoorsel oorgedra om die eksperimente te voltooi

TABEL 2: HF-lotreaktor eksperimente

\begin{tabular}{l|c|c|c}
\hline Eksperiment & Massa $\mathrm{CaF}_{2} \mathbf{( g )}$ & Massa $\mathrm{H}_{2} \mathbf{S O}_{4}(\mathbf{g})$ & Verwagte massa $\mathrm{HF}(\mathbf{g})$ \\
\hline $\mathrm{HF} 1$ & 64.6 & 406 & 33.1 \\
\hline $\mathrm{HF} 2$ & 64.6 & 406 & 33.1 \\
\hline
\end{tabular}

Tabel 3 bevat ' $n$ beskrywing van die voltametriesekurwe ondersoeke. Hierdie twee eksperimente is direk na mekaar afgehandel om die resultate te kan vergelyk.

TABEL 3: Voltametriese eksperimente

\begin{tabular}{ll}
\hline Eksperiment & Beskrywing \\
\hline F1 & Die elektriese voorspanning word stapsgewys met ongeveer 1V \\
& verhoog en die stroomlesing genoteer sodra dit gestabiliseer \\
& het. Dit word herhaal tot waar die stroomlesing afplat met \\
& verandering in spanning en dan weer toegepas met $1 \mathrm{~V}$ afnames \\
& in die spanning. \\
\hline F2 & Die toegepaste spanning word stapsgewys met $1 \mathrm{~V}$ verhoog tot \\
& die verwagte bedryfspanning van $12 \mathrm{~V}$ en hoër tot' $n$ maksimum \\
& van $18 \mathrm{~V}$ om die effek op stroom waar te neem. By elke stelling \\
& word ongeveer 5 minute se data versamel. \\
\hline
\end{tabular}

\section{Resultate en bespreking}

Die massa HF vervaardig vir die HF eksperimente word saam met die omskakelings-rendement in Tabel 4 gerapporteer. Anhidriese HF se wit voorkoms as damp bevestig die anhidriese aard van die produk. Die reaktor is makliker om skoon te maak na afloop van 'n lopie sodra die reaktor koud genoeg is om te hanteer. Indien die reaksiemengsel oornag gelos word om af te koel, vorm dit 'n harde koek wat moeilik van die wand afgeskrop word. Dit is weens veiligheidsredes ook ongewens om die reaktor aggressief te skrop. 
Met eksperiment HF1 is die reaktorflens nie styf genoeg vasgedraai nie. Dit het tot inlekking van lug gelei en die oordrag van $\mathrm{HF}(\mathrm{g})$ na die vat is belemmer. Die lotreaktor was afgeseël en vakuum is vir 'n tweede maal op die oordragsvat getrek. Sodoende kon die lopie voltooi word met 'n voldoende drukverskil. Oorblywende lug wat weer in die oordragsvat akkumuleer het, is na die eksperiment m.b.v. die vakuumpomp verwyder deur dieselfde metode te gebruik.

TABEL 4: HF-lotreaktor eksperimentresultate

\begin{tabular}{l|c|c}
\hline Eksperiment & Massa HF (g) & Omskakelingsrendement (\%) \\
\hline HF1 & 25.4 & 77 \\
\hline HF2 & 23.5 & 70 \\
\hline
\end{tabular}

Die HF oordragsvat is voor die laai van die fluoorsel gebruik vir die stoor van voorafgeproduseerde HF met 'n vroeër weergawe van die lotreaktor. Daar is ongelukkig nie van hierdie HF rekening gehou nie en die massa oorgedra totdieselvoor gebruik was $97.4 \mathrm{~g}$. Dieelektrolietsamestelling was dus KF·2.77HF.

Die voltametriese data vir eksperiment F1 word in Figuur 6 weergegee. Die eerste stroom is by 'n spanning van $5.6 \mathrm{~V}$ waargeneem. Die omkeerbare spanning vir die reaksie is 2.9 V (Rudge, 1971). Die waargenome bo-potensiaal vir die sel is dus $2.7 \mathrm{~V}$. Die vervaardiging van $\mathrm{F}_{2}(\mathrm{~g})$ is bevestig met KI (aq) benatte papier by die fluooruitlaat. Die oplossing het onmiddellik swart verkleur en dui dus op die teenwoordigheid van fluoorgas.

Die datapunte versamel gedurende eksperiment F2 is elk een sekonde uit mekaar geneem en is as punte met ' $n$ deursigtigheid van $80 \%$ in Figuur 7 gestip. Met hierdie data is 'n lineêre regressielyn soortgelyk aan die regressielyn in Figuur 6 verkry. Die regressielyne tesame met korrelasiekoëffisiënte vir beide eksperimente word in Tabel 5 gerapporteer. Die pieke wat waargeneem word in Figuur 7 kan teenwoordig wees as gevolg van massa-oordrageffekte.

TABEL 5: Regressielyne en korrelasiekoëffisiënte vir voltametriese data

\begin{tabular}{l|c|c}
\hline Eksperiment & Regressielyn & Korrelasiekoëffisiënt \\
\hline F1 & $\mathrm{I}=0.259 \mathrm{~V}-1.46$ & 0.920 \\
\hline F2 & $\mathrm{I}=0.255 \mathrm{~V}-1.41$ & 0.890 \\
\hline
\end{tabular}

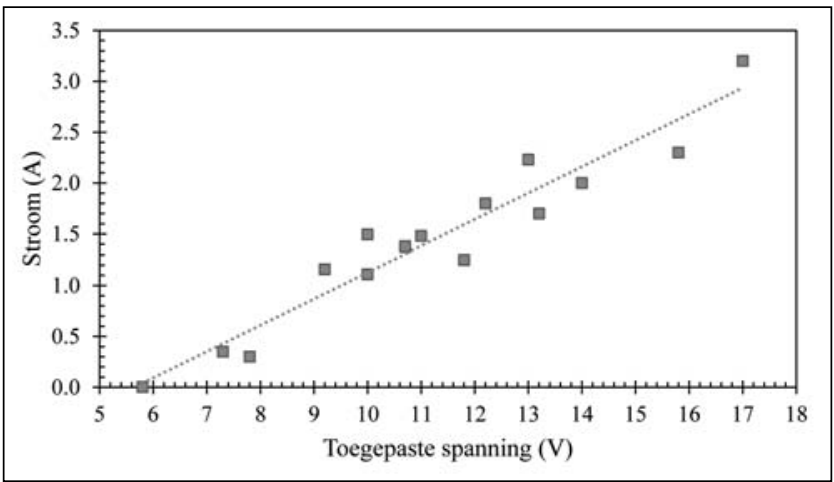

FIGUUR 6: Fluoorsel voltametriese kurwe, eksperiment F1.
Gedurende eksperiment F1 en F2 is daar waargeneem dat die fluooruitvloei uit die sel wissel. Hierdie waarneming het gepaard gegaan met die hoorbare herkombinasie van die produkgasse en dui daarop dat die elektrodes nie tot so naby aan mekaar gesak moet word nie. Ook was daar moontlik verstopping van die $1 / 4$ " buise. Die hoogte wat toegelaat is vir die gas om uit die elektroliet vry te breek, was dus nie voldoende nie

\section{Gevolgtrekking}

Die ontwerpte laboratoriumproses is suksesvol en veilig bewys vir die laboratorium-vervaardiging van fluoorgas. Die HF-lotreaktor het 'n omskakelingsrendement van $70 \%$ vir die beperkende reagens. Anhidriese HF is suksesvol vervaardig, gestoor en oorgedra. Die fluoorsel is suksesvol bedryf en toon'n bo-potensiaal van 2.7V. Die herkombinasie van die produkgasse dui op elektrodes wat te na aan mekaar gemonteer is. Die $1 / 4^{\prime \prime}$ buise se verstopping dui daarop dat die vrybreukhoogte vir makliker bedryf hersien moet word. In hierdie stadium is daar nie gepoog om die vervaardigte produkte analities te karakteriseer of om die kontaminante te identifiseer en kwatfiseer nie. Weens die korosiewe en gifige aard van die produkte is dit moeilik en moeisaam en verg substantiewe addisionele werk.

\section{Bylae}

Die proses wat hier bo beskryf word, is gevaarlik om te bedryf vanweë die aard van die reaksies sowel as die reaksieprodukte. HF is 'n kleurlose vloeistof of gas met 'n sterk en irriterende reuk (NECSA, 2017). Blootstelling aan $\mathrm{HF}$ is ' $\mathrm{n}$ baie ernstige saak. HF is 'n swak suur, maar penetreer menslike vlees baie vinnig en veroorsaak ernstige chemiese brandwonde. Dit word dus as baie toksies en korrosief geklassifiseer vir blootstelling deur inasem sowel as velaanraking. Om die risiko binne perspektief te plaas: die dood van'n persoon is moontlik met'n blootstellingsarea so groot soos een handpalm. In die geval van blootstelling moet die kontakarea onmiddellik vir 15 minute met koue water gespoel word, daarna met kalsiumglukonaatjellie bedek word. Addisionele professionele mediese aandag na die noodhulpprosedure is verder noodsaaklik. Indien HFdampe ingeasem word, moet die persoon dadelik in 'n half-regop posisie in vars lug geplaas word. Kunsmatige asemhaling is moontlik nodig en mediese sorg moet so gou

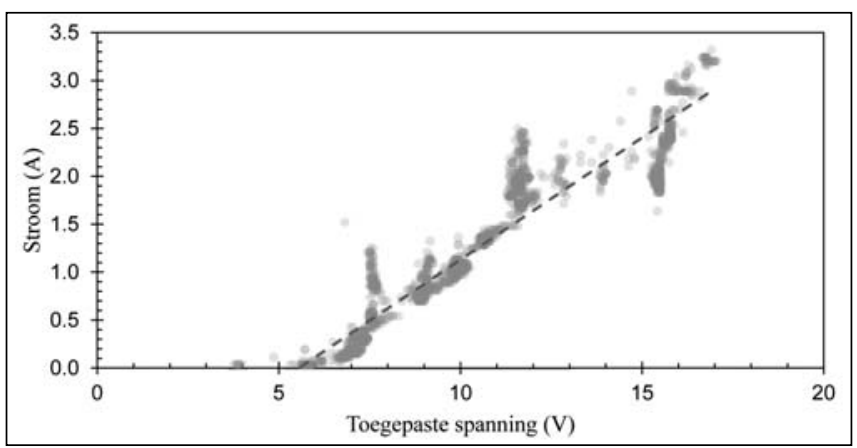

FIGUUR 7: Fluoorsel voltametriese data, eksperiment F2. 
moontlik verkry word (International Labour Organization, 2017b).

Die aard van blootstelling aan $\mathrm{F}_{2}$ is van soortgelyke erns. Vir inaseming word dieselfde stappe as met HF gevolg (International Labour Organization, 2017a). Blootstelling aan die vel moet behandel word deur die area vir 15 minute met koue water te spoel waarna klere verwyder word en die area soos vir HF, vir 15 minute gespoel word. Mediese versorging na blootstelling is noodsaaklik.

Enige uitvoerder van hierdie proses word aangemoedig om veiligheidsreëls en -klere se gebruik streng toe te pas (NECSA, 2017, Rudge, 1971). Opleiding in die hantering van hierdie materiale is verder noodsaaklik. Die outeurs het geen eksperimente buite 'n dampkas bedryf nie. Verbruikers word aangemoedig om ten alle tye 'n chemiesbestande laboratoriumjas en volgrootte gesigmasker te dra. Hande moet met kalsiumglukonaatjellie gesmeer word voor 'n eerste laag nitrielhandskoene aangeterk word. Aangesien handskoene mag skeur gedurende die hantering van die toerusting, moet hierdie handskoene ook buite met jellie gesmeer word en 'n buitenste laag handskoene word bo-oor die eerste vereis. Bedekte skoene en 'n laboratoriumbroek is ook noodsaaklik.

\section{Verwysings}

Aigueperse J, Mollard P, De Villiers D, Chemla M Faron R Romano R, Cuer JP. 2000 Fluorine Compounds, Inorganic. In: ELVERS, B. (ed.) Ullmann's Encyclopedia of Industrial Chemistry. Weinheim, Germany: Wiley.
Cady GH, Rogers DA, Carlson CA. 1942. Preparation of fluorine. Industrial Engineering Chemistry, 34, 443-448.

Craig BD, Anderson DS. 1995. Handbook of Corrosion Data, Materials Park, Ohio, United States of America, ASM International.

Francis R. 2009. The performance of stainless steels in concentrated sulphuric acid. Stainless Steel World, 1-4.

Groult H. 2003. Electrochemistry of fluorine production. Journal of Fluorine Chemistry, 119, 173-189.

Groult H, Simon C, Mantoux Fa, Lantelme F, Turq P. 2005. Experimental and theoretical aspects of the fluorine evolution reaction of carbon anodes in molten KF-2HF. In: Nakajima T \& Groult H. (eds.) Fluorinated Materials for Energy Conversion. Amsterdam, Nederland: Elsevier.

Leech HR. 1949. Laboratory and technical production of fluorine and its compounds. Quarterly Reviews of the Chemical Society, 3(1), 22-35.

Macur M. 2016. The complexity of machining lead and lead-based products [Online]. Available: http://vulcangms.com/2016/05/31/machining-lead-leadbased-products/ [Accessed 16 Oktober 2017].

NECSA 2017. HF Safety Induction. Pelindaba, South Africa: Nuclear Energy Corporation of South Africa.

Pauling L. 1957. College Chemistry, San Francisco, United States of America, W H Freeman and Company.

Ring RJ, Royston D. 1973. A Review of Fluorine Cells and Fluorine Production Facilities, Sydney, Australië, Australian Atomic Energy Commission.

Roustand H, Caire JP, Nicolas f, Pham P. 1998. Modelling coupled transfers in an industrial fluorine electrolyser. Journal of Applied Electrochemistry, 28, 237 . 243.

Rudge AJ. 1971. Production of elemental fluorine. In: KUHN, A. J. (ed.) Industrial Electrochemical Processes. Amsterdam, Nederland: Elsevier.

Shia G. 2003. Fluorine. In: SEIDEL, A. \& BICKFORD, M. (eds.) Kirk-Othmer Ecyclopedia of Chemical Technology. Hoboken, New Jersey, United States of America: Wiley and Sons.

Walsh F. 1993. A First Course in Electrochemical Engineering, Romsey, England, The Electrochemical Consultancy. 